\title{
食用植物油業界の現状と展望
}

\author{
東森宏 \\ 社団法人 日本油脂協会 (東京都中央区日本橋 3-13-11)
}

\section{Present Situation of Edible Vegetable Oil Industry in Japan}

\author{
Hiroshi Higashimori \\ Japan Oilseed Processors' Association \\ (3-13-11, Nihonbashi, Chuo-ku, Tokyo)
}

日本の食用油業界は原料の大部分を輸入に依存しなけ ればならない。そして油脂原料の国際相場は, 原料の豊 作と不作, 油脂製品の国際的需要動向, その他それらを 材料にした国際的投機筋の暗躍などによって極めて激し く騰落を繰り返している。相場の波乱の中にもられ, 日 本の食用油業界む昭和 50 年には巷間 800 億円という大赤 字を余儀なくされ，昨今はまた為替相場の激動の中で円 安という直撃弾をらけ, 再び㛜しい試鍊の場に立たされ ている。その間業界ならびにそれぞれの企業において は, 脱相場の方策を進める之か, 合理化, 省力化を進め 軽量経営によって変化汇対応できる企業体質の強化をは かるとかの努力を重致ているが，一方では原料の入手情 況の関係からも大豆，なた数を中心とした集約化も着実 に進行している。軽量と集約化, これは現下の食用油業 界の一つの方向性ではあろうが，もち万んそれだけで日 本の食用油業界の命題が解決されるものではなからら。 油脂, 油かすの生産と同時に, 生産された油脂と油かす にいかにより高い付加価值をつけその高度利用をたかめ てゅくかといらことと，より個性的な製品の創造，これ らが今後のテーマになってくるのではなからうか。

\section{搾油原料は大豆となたねに集中化}

元来日本の食用油業界は世界の各地から有利な原料を 入手して搾油するところにその特色の一つがあり, 昭和 40年代の初めころまでは大豆, なた叔の外绵実, サフ ラワー, カポック, コプラ, あるいはひまわりと各種の 原料をかなりの量搾油していた。全搾油原料は昭和30年 に 936 千 $\mathrm{t}$ であったが昭和40年には 2,695 千 $\mathrm{t}$ と 2.9 倍 になり, 昨昭和 53 年には 5,217 千 $\mathrm{t}$ と昭和 30 年に比べ 5.6 倍になった。そしてその間国産原料は昭和 40 年代の 初めまでなた放が 10 万 $\mathrm{t}$ 前後利用されていたが，その 後はほとんどなくなり，現在では米ぬかだけとなった。 全処理原料のなかに占める大豆のウエイトは昭和 30 年に
$53.9 \%, 35$ 年 $48.6 \%, 40$ 年に $51.3 \%$ であったものが、 45年には $57.9 \%$ となり, 更に昨 53 年には $63.2 \%$ に なった。またなたね怊和 30 年に $15.5 \%$ であったもの が，35年に $12 \% ， 40$ 年に $8.3 \% ， 45$ 年には $10.4 \%$ に なった。昭和 30 年, 35 年に比率が高いのは国産なた数 の生産が際立って大きかったからで，その後国産が減っ て輸入に切り替えられてきた。その輸入なた权のウエイ トも急増し，昨 53 年には $16.5 \%$ となった。昭和 40 年 代には大豆，なたねを合わせて全体の60\% 位であった ものが，昨今は $80 \%$ と急増してきた。特に 53 年は円 高の影響で油脂製品の価格が安くなり需要が急增したの で, 大豆, なた㸚の処理も大幅に増大した。

これは逆に大豆, なた权以外の油脂原料のウエイトは 大きく減少していることを物語るものである。綿実はか って年間 30 万 $\mathrm{t}$ 近くの揬油を行ったものであるが, 近 時現地搾油が進んで輸出们向けられる量が少なくなり， 原料での入手が困難となり，このところは年間 10 万 $\mathrm{t}$ に達しない情況である。サフラワーもかっては 10 万 $\mathrm{t}$ 位輸大していたが, 昨今は 2 万 $\mathrm{t}$ 前後, カポックも多い ときは 5 万 $\mathrm{t}$ 位あったが，昨今は 1 万 $\mathrm{t}$ 前後，ひまわり は皆無。ごま, コプラなども横ばいかあるいは漸減傾向 にあり，国産米好米食ばなれから，ぬかの発生量は 減少の方向である。増加しているのはとうもろこしだけ である。従ってこれらを原料とする油脂はそれぞれ個有 の風味や成分を生かした用途に向けられることになる。 大豆はアメリカを中心に年々生産は上向き，なた放もカ ナダを中心に品種改良や增産が進められており，いずれ も大量輸送が可能である。日本の製油工場は 40 年代にス ケール・メリットを追求しての大型工場を数多く作った ので, 原料の大量入手は絶対に必要な条件であり, 大豆 かす，なた齐かすの需要增大などもあって，原料の供給 事情と需要条件が完全にマッチし, 大豆, なた权の搾油 
が急増することとなった。特にここ両 3 年における油脂 原料の処理増加は専ら大豆となた称に限られたような形 となり, 大豆については昭和 50 年に 2,620 千 $\mathrm{t}$ の処理 であったものが, 51 年 2,701 千 $\mathrm{t}, 52$ 年に 2,878 千 $\mathrm{t}$ になり，特に昨 53 年は 3,296千. $\mathrm{t}$ になり，この 3 年間 に676千t，率にして 25.8\% 増加した。またなた权に ついては昭和 50 年に 701 千 $\mathrm{t}$ であったものが，51 年に 636 千 $\mathrm{t}, 52$ 年に 751 千 $\mathrm{t}, 53$ 年には 861 千 $\mathrm{t}$ になり, 50 年に比べ 160 千 $\mathrm{t}$ 率にして $22.8 \%$ の増加になってい る。全体の处理原料は昭和 50 年で 4,338 千 $\mathrm{t}, 53$ 年は 5,217 千 t であるから 879 千 t 増加したことになり，大 豆となたねで 836 千 $\mathrm{t}$ を占めている。

\section{大豆となたねは増産の方向}

日本で㩁油する油脂原料はますます大豆となたねのウ エイトを高めているが，世界における大豆となた权の生 産，供給事情はどうなっているか。

世界におけるおもなる大豆の生産国は 表-1 のとおり アメリカ, 中国の北半球グループに加え, ブラジル，ア ルゼンチンがここ数年の間に大きく生産を伸ばしてき た。しかし中国は 1,200 万 $\mathrm{t}$ 程度の生産はあるものの国 内需要が精一杯で海外に向けるまでのものはなく, ブラ ジルも 1,000 万 $\mathrm{t}$ 位の生産はあるが国内での㩁油用に充 当するものを優先し，このところ原料での輸出は 100 万 $\mathrm{t}$ 位, アルゼンチンからは 200 万 $\mathrm{t}$ から 250 万 $\mathrm{t}$ 位が輸 出用に積み出されるにすぎない。1977/78 年の全世界の

表-1 大豆の国際需給

(単位: 千 $\mathrm{t}$ )

\begin{tabular}{|c|c|c|c|c|c|}
\hline & & $75 / 76$ & $76 / 77$ & $\begin{array}{c}77 / 78 \\
\text { (見込み) }\end{array}$ & $\begin{array}{c}78 / 79 \\
\text { (見込み) }\end{array}$ \\
\hline \multirow{2}{*}{ 期 } & 米 & 5,036 & 6,658 & 2,801 & 4,383 \\
\hline & ブ ラ ジ ル & 4,200 & 3,800 & 4,800 & 3,300 \\
\hline 初 & フルゼンチン & 295 & 358 & 532 & 530 \\
\hline 在 & 本 & 306 & 409 & 450 & 440 \\
\hline \multirow[t]{2}{*}{ 庫 } & $\exists$ ヨッパ & 490 & 466 & 245 & 409 \\
\hline & 鄗 & 10,237 & 11,691 & 8,828 & 9,062 \\
\hline \multirow{5}{*}{ 生 } & 国 & 42,133 & 35,042 & 47,948 & 50,800 \\
\hline & ブ ラ ジル & 11,227 & 12,513 & 10,360 & 12,100 \\
\hline & フルゼンチン & 695 & 1,400 & 2,700 & 3,500 \\
\hline & 中 & 12,300 & 12,000 & 12,200 & 12,500 \\
\hline & 日 & 126 & 110 & 111 & 190 \\
\hline \multirow[t]{2}{*}{ 産 } & 他 & 4,384 & 3,585 & 4,246 & 4,430 \\
\hline & 合 & 70,865 & 64,650 & 77,565 & 83,520 \\
\hline \multicolumn{2}{|r|}{ 給 } & 81,192 & 76,341 & 86,393 & 92,582 \\
\hline \multirow{3}{*}{ 需 } & 搾 油 用 & 57,495 & 55,867 & 65,362 & 69,190 \\
\hline & 種子及び他用途 & 10,644 & 10,473 & 10,862 & 11,540 \\
\hline & $\begin{array}{l}\text { 口ス・ドッケー } \\
シ ゙\end{array}$ & 62 & 1,173 & 1,107 & 1,352 \\
\hline 要 & 合 & 69,501 & 67,513 & 77,331 & 82,082 \\
\hline tol & 朶 在 庫 & 11,691 & 8,828 & $9,0 \in 2$ & 10,500 \\
\hline
\end{tabular}

注 1. Oil World, March 30 (1979)

2. ブラジルの 79 年産大豆の生産量は 11,000 千 $\mathrm{t}$ 台との 予測も蓑る。
輸出量は 2,270 万 $\mathrm{t}$ と推定され，らちアメリカが 1,970 $\mathrm{t}$ であるから実に $87 \%$ を占めている。日本は地理的な 関係もあってほとんど全量をアメリカに依存している。

アメリカに拈ける大豆の生産はどうかといらと，必ず しもここ数年の動きは安定的でない。1972 年の生産量 は 34,581 千 $\mathrm{t}, 73$ 年 42,103 千 $\mathrm{t}, 74$ 年 33,067 千 $\mathrm{t}$, 75 年 42,103 千 $\mathrm{t} 76$ 年 35,054 千 $\mathrm{t}, 77$ 年 47,955 千 $\mathrm{t}$ で78 年は 50,159千 $\mathrm{t}$ が見込まれている。すなわち, こ の 6 年間汇 3 回, 72 年, 74 年亡 76 年は不作湴舞称 ており，それらの年にはシカゴ大豆は暴騰した。

1975 年からの世界の大豆需給情況は 表-1 のとおりで ある。アメリカ大豆の生産も豊凶を繰り返してはいる が，ここ2 年ばかりは着実に增産の方向をたどり，世界 全体の生産量に占める比率も高まっている。しかし㩑油 需要も着実に高まり，生産の少なかった 1976年/77 年に ついては期末在庫が 8,828 千 $\mathrm{t}$ とかなり減少している。 1978 年のアメリカ大豆は史上初の 5 千万 $\mathrm{t}$ を上回る大 豊作であるが，ブラジルの生産が予想より少ないことか ら，期末在庫は 3,817 千 $\mathrm{t}$ とかり減少するだろらと米 農務省はみている。搾油用, 輸出用が 450 万 $\mathrm{t}$ 位増大寸 るものと推定している。

またなた秃については，日本はほとんど全量をカナダ に依存しており，カナダの需給情況をみるとここ 2 年位 生産は順調に伸びている。カナダなたねの生産は 1975 年 1,749 千 $\mathrm{t}, 76$ 年の生産注前年末の在庫が多かった ため 837 千 $\mathrm{t}$ と大幅な減少をみたが, 以後恢復し, 77 年 1,973 千 $\mathrm{t}, 78$ 年には 3,470 千 $\mathrm{t}$ と增大している。輸出 量も 74 年から 75 年には 600 千 $\mathrm{t}$ 台であったものが 76 年には 1,0184 千 $\mathrm{t}, 77$ 年 1,020 千 $\mathrm{t}$ になり 78 年は 1,600 千 $\mathrm{t}$ を見込んでいる。油及びかすの品質向上のた めの品種改良も極为て積極的汇進められており, 当分は 安定的な供給が期待できるようである。日本で注昨年 10 月に新しい品種から生産されるなた㸚油かすを飼料用へ 用途を拡大するよらカナダ国連邦政府とともにシンポジ ウムを開いて，関係業界にも広く呼びかけを行った。昨 年の生産が大幅に伸びたにもかかわらず，国際的な油脂 原料の堅調ななかでカナダのなたねも比較的高值を維持 しているので，増産の傾向は当分続くであろう。

以上の上うに大豆，なた斌については年により不作も あるものの，大きな流れとしては増産の方向にあり，そ の他の油脂原料が横ばいあるいは漸減傾向, 更には国に より原料での輸出を認めないなどの環境の中で，大豆， なたねは安定性の高い原料といわなければならない。そ してアメリカもカナダも広大な土地を持ち, 進しだ農業 技術をもっているので，大豆やなたねに対する需要が更 に高まれば，生産を更に伸ばす力も持っている。そのよ うな点から考えれば，アメリカの大豆，カナダのなた权 上いらのは将来更に増産が期待され世界の油脂原料の中 
でのウエイトも伸ばしてくるものと思う。

\section{3 年の食用油消費量は $8 \%$ 增}

食用油脂の消費量は昭和 44 年で 1 人年間 $9.0 \mathrm{~kg}$ であ ったものが昨 53 年には $12.8 \mathrm{~kg}$ と，この 10 年間に $42 \%$ の伸びを示した。このうち昭和 49 年と 50 年の 2 か年 は高值と不況のため隇少したが，その他の年はおおむ叔 4 ないし $5 \%$ の伸び率を維持し, 特に昨 53 年に洋前 実績 $11.9 \mathrm{~kg}$ よりも $8 \%$ 增加した。これは 53 年の春以 降続いた円高のため, 原料の入手価格が安くなり，その 分を製品の值下げ，特に主として食用油の洒格引き下げ にあてたため末端仙格がかなり低下し需要喚起㳊役立っ たのではない亦とみられている。

食用油脂のなかには植物油上動物油とがあり, 植物油 としては大豆油, なたね油, 綿実油, 米好油等植物性 油脂原料から生産した食用油があり, 動物油としては牛 脂, 豚脂, 魚油, 鯨油など動物性の食用脂がある。こし て $7 \sim 8$ 年前までは全食用油脂消費量の中に占的る植物 性食用油と動物性食用脂の比率は約 $75 \%$ と $25 \%$ であ った。ところがその後動物油洨コレステロールの関倸で 敬遠されるとか, 生産が充分でないとかの理由から伸び 悩々，比率注次低下し現在は $20 \%$ を下回る状況々な って扮り，心わって植物性食用油の比率が高まってい る。昭和 53 年の実績では食用油脂全体の消費量は 1,574 千 $\mathrm{t}$ ミ゙, うち植物油は 1,282 千 $\mathrm{t}(81.45 \%)$ で動物油は 292 千 $\mathrm{t}(18.55 \%)$ であり, 前年に比へ動物油の比率注 いくらか高まったものの，20\% を下回る率になってい る。

さ下昭和 53 年の植物性食用油消費量 1,282 千 $\mathrm{t}$ の内 訳をみてみよう。品目別に消費量の多いものとしては大 豆油 560 千 $\mathrm{t}(43.6 \%)$, なた权油 351 千 $\mathrm{t}(27.4 \%)$, 米油 60 千 $\mathrm{t}(4.7 \%)$ などがあり, また近年輸入が増加 乙各方面に広く使用されるようになったパーム油は 129 千 $\mathrm{t}(10 \%)$ になり，その他上してはやし油 40 千 $\mathrm{t}$,とう もろこし油 49 千 $\mathrm{t}$, 綿実油 48 千 $\mathrm{t}$ などとなっている。 そして用途之しては家庭用, 業務用, 加工用の 3 つに分 類さ礼ている。家庭用というのは一般家庭でそのまま揚 げもの，Wためもの，サラダなどに使用されるもので, 普通小かん，小びんに入った形で流通している。業務用 は揚げ菓子，油揚げ，食堂，ホテル，スナックなどや集 団給食用など営業用に，そのままの形で料理に使うもの をいい，主上して一斗かん $16.5 \mathrm{~kg}$ に詰められた形で流 通している。加工用は二次製品の原料として食用油を使 用す公分野をいい, マーガリン, マヨネーズ, ショート ニングなどで近年消費量を大きく伸ばしている。工場用 であるから流通形態はお扔む叔ドラムかん，タンク，口 ーリー車などで大量に運ばれる。それらの用途別に53年 の消費実績をみると

家庭用は 404 千 $\mathrm{t}$ で前年対比 108.9\%
業務用注386千 $\mathrm{t}$ で前年対比 $110 \%$

加工用は 492 千 $\mathrm{t}$ で前年対比 $102.3 \%$ となっている。加工用の伸び率が少ないのは, この年バ 一ム油の輸入が前年より減少しているため, 動物油の使 用が多かったなどのためであろう。加工用の内訳はマー ガリン, ショートニング用 283 千 $\mathrm{t}$, 、ヨネーズ,ドレッ シング用 137 千 $\mathrm{t}$ ，その他（ポテトチップなどのスナッ ク食品やインスタントラーメン用） 72 千上なってい る。家庭用は順調に消費量を伸ばしており, 業務用は一 般経済環境の好不況と価格の水準により振幅が激しく, 年により大きく減少するときもあり, 加工用はマーガリ ン, マヨネーズ, ショートニングの伸びにつれ順調な伸 びを示している。

な扮植物油としては食用油の外に, 印刷インキ, 塗料 セッケンなどに向けられる純然たる工業用があり, あま に油,ひまし油などを中心に大豆油などの食用油も一部、 はこの方面に向けられ，53年の消費実績は199千 t にな っている。しかし化学合成品の進出などによりこの分野 の消費㵟增に止まっている。

\section{脱脂大豆の需要屯大幅增}

食用油産業というのは食用油の生座上同時化植物性油 かすを生産しており，油脂原料のなかで最も大きい大豆 についてみると, 脱脂大豆 (大豆かす) は単位当たりの 大豆に対し，物量的には 79\%，侕格的には約 $65 \%$ を占 めており，いずれの面からみても食用油よりウエイトの 高い存在である。従って食用油業界というのは油ととも にかすについても健全な需要がないと成り立たない産業 であり，特に大豆製油についてはそのことは殊更重要で ある。食用油を語る場合，かすについてふれないと片手 落ちになるのでかすの中心をなす脱脂大豆について昨今 の需給関係をみることとする。昭和 53 年における植物油 かすの全生産量は 3,720干 $\mathrm{t}$ で，うち脱脂大豆は 2,543 千七であるから $68 \%$ を占めることとなる。

昭和 50 年からの脱脂大豆の需給実績と 54 年の見通し は表-2のと抢りである。全体の需要莗のうち $15 \%$ 位 が食品用としてしょう油の原料や豆腐粉, 大豆タンパク 食品の原料として使用され, 残りの $85 \%$ 位が飼料用と して配混合飼料に向けられている。従って脱脂大豆の需 要動向は主として配合飼料の動きに左右される分野が大 きい。配合飼料の生産量は昭和 48 年に 18,084 千 $\mathrm{t}$ を記 録し, その後 49 年, 50 年と減退したあと 51 年には再び 18,094 千 $\mathrm{t}$ と 48 年の水準を回復し，以後は 52 年 19,527 千 $\mathrm{t}, 53$ 年には更に 20,838 千 $\mathrm{t}$ と前年比 $6.7 \%$ の増加 を示し, ここ両 3 年は極为て順調に伸でている。一方植 物油かすの配合については落花生油かすの使用がアフラ トキシンの問題から近時減少しており, また綿実油かす やサフラワー油かすについては国内生産量が減少したこ とも影響し, より良質のタンパク源への志向も強く, こ 
表-2 大豆油かすの需給実績及び見通し

(単位: 千 $\mathrm{t}$ )

\begin{tabular}{l}
\hline 区分 \\
\hline \multirow{2}{*}{ 年次 $(\mathrm{CY})$}
\end{tabular}

の上ころ脱脂大豆の使用割合は年々向上している。すな わち昭和 48 年から 49 年にかけては 9.9 \% であったもの が，50 年には $10.5 \%$ になり 52 年には $10.9 \%$, 更に 53 年には $11.3 \%$ にまで上昇した。配合飼料の生産が着実 に上昇し，配合率が増加するから，飼料用の脱脂大豆需 要量はかなりの高い伸び率を示している。表でみるとお り昭和 52 年には 2,230 千 $\mathrm{t}$ が飼料用に使われ，前年比 $14 \%$ 增，また 53 年は 2,483 千 t で前年比 11962 年 連続高い伸びを記録した。

急増する脱脂大豆の需要ををかなうためには到底国内 で生産されたものだけでは間に合わず，かつ製油メーカ 一としても脱脂大豆の生産を増やせば食用油の過剩生産 といら問題があるので，このところ脱脂大豆の輸入が増 加の傾向にある。昭和40年代の中ごろまでは年間で50千 $\mathrm{t}$ 位の輸入であったものが，51 年には 193 千 $\mathrm{t} ， 52$ 年 には 314 千 $\mathrm{t}$ が輸入され，更に 53 年には 340 千 $\mathrm{t}$ が輸 大された。ヨーロッパではブラジルからの脱脂大豆がか なり輸出攻勢をかけ，EC の製油企業を悩ませているよ うであるが，日本に輸入されているのはほとんどアメリ カものであり，輸入ものが直接市場に混乱を与えている ケースは少ない。しかし今後上も300千 $\mathrm{t}$ 前後の翰入は 続きそうである。

\section{ECでも大豆搾油は増大}

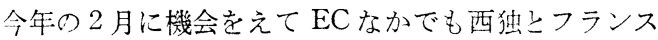
の製油事情を調査した。それらをもとにして，昨今の $\mathrm{EC}$ 製油業界のことにいくらか子れてみることとした い。ECにおける油脂上油かすの需要をみた場合，油脂 については消費が一定水準に達しており，市まり伸長が 期街できないのに対し，油かすの需要はまことに䟚盛で ある。1977年の EC 全体の植物油かすの消費量は 16, 199 千 $\mathrm{t}$ で，大豆かすだけについてみると 10,771 千 $\mathrm{t}$ であ る。これに対し域内での生産量は大豆か寸だけについて は7.089千 tであり，植物油かす全体で 8,690 千 $\mathrm{t}$ であ
る。つまり全体では 7,509 千 $\mathrm{t}$ 不足し，大豆かすだけを みると 3,682 千 $\mathrm{t}$ 不足しており, 他地域から輸入してま かなったことになる。特に近年の特徴的な事柄としてブ ラジルから大豆かすのかなり強い輸出攻勢が EC に向け られているようである。フランスでは 1977 年には年間 でブラジルの大豆かすを 914 千 $\mathrm{t}$ 輸入したが，1978 年 には1月から 11 月までで既に 1,104 千tを輸入してい る。西独でもブラジル大豆かすの攻勢には頭を痛めてい るようである。

植物油かす，特に大豆かすに対する強い需要があるに もかかわらず域外からの輸出攻勢に脅かされていたので は EC 製油業の存立にかかわると，このところ超大型の 低コスト工場が各国に次々と建設されている。アムステ ルダムのカーギルは日産能力 $3,000 \mathrm{t}$ に拡張しロッテル ダムのユーロポートは $4,500 \mathrm{t}$ といわれている。西独の 製油工場も $3,000 \mathrm{t}$ か $3,500 \mathrm{t}$ 級が 3 工場, $2,000 \mathrm{t}$ 級が 2 工場， $1,000 \mathrm{t}$ から $1,300 \mathrm{t}$ 級が 3 工場， $500 \mathrm{t}$ 級 が 4 工場, 合計 11 社， 12 工場で日産能力約 2 万 $\mathrm{t}$ とな り，西独の油脂原料の 95〜96\% を処理しているようで ある。フランスも年間処理能力 400 千 $\mathrm{t}$ の工場が 2 つ, 300 千 $\mathrm{t}$ 級が 2 つ, 100千 $\mathrm{t}$ 級が 2 つと中小で 100 千 $\mathrm{t}$ 位とされ，現在ボルドー港に地元の中型工場が数社で協 同して年間能力 550 千 $\mathrm{t}$ の大型工場を建設中であり,こ の秋からか(稼)動に入る予定とされている。その他ベル キーやイギリスのリバープールにも大型工場が建設され た。このような製油能力の増大と大型化の背景について は大豆かすの旺盛な需要はもちろんであるが, 次のよう な理由をあげることができる。

1） EC での植物油かす，特に大豆かすの需要が増大 している。

2) 近時ブラジルの大豆かすがダンピングとも受けと れるような超安值で EC 圈内に輸出攻勢をかけ, EC の 製油産業を脅かしているので，これに対抗できる低コス トの合理化工場が必要になった。

3）落花生やコプラなどの原料の入手が従来のように 容易でなくなり，大豆が比較的安定的に入手しらる原料 となり，これが工場の大型化を誘導している。

4）合理化を推進する過程で中小工場を統合して大型 工場を建設することも行われた。

5) 東欧圈の需要も旺盛となってきた。

6) 西独やフランスをはじめ，EC 各国で落花生油, オリブ油更には綿実油などの需要が徐々に大豆油に変わ りつつあり, 大豆油の需要が増大してきた。

極度に省力化した大型工場の建設が進められ，その過 程で工場の集約化も急速に進められている。

そして EC においても大豆の処理量は大きく増加して いる。1965 年における $\mathrm{EC}$ 全域の大豆処理量は 2,825千 tであったが, 1977 年には 8,864千 $\mathrm{t}$ と 3.1 倍になっ 
た。西独では 1975 年に既に 3,463千 $\mathrm{t}$ を処理している。 日本は 1965 年に 1,314 千 $\mathrm{t}$ の大豆を処理し 1977 年は 2,879 千 $\mathrm{t}$ であるから 2.2 倍である。全体の伸び率も EC の方が高いし, 西独も 1965 年の処理量をみれば 1 , 290 千 $\mathrm{t}$ であるから，1973 年ころまではほぼ日本と同じ 程度の大豆処理量であったが，その後日本よりも大幅な 伸びを示したことになる。

食用油の需要状況にもかなり変化を来している。例え ばフランスについてみると，フランスでは食用油といえ ば落花生油といわれるほど広く愛用され，1960年台まで は全体の食用植物油のうち80\%が落花生油で占められて いた。しかしその後落花生の原料の入手が逐次困難とな り, 油での輸入を余儀なくされる形となってきた。一方 大豆かすなど植物性油かすの需要も増大してくるので, 落花生は油で輸入し，大豆かすなどもかすで輸入するこ とは，フランスにとって決して好ましい方向ではなく， かつ経済的なことでもないので, 逐次大豆油など落花生 油以外の需要哃起の努力も重ねられ, その結果食用油の なかでのウエイトは減少し, 1978 年には 46\% になっ た。今一つフランスについての問題はなたね油である。 フランスでは現在 40 万 $\mathrm{t}$ から 50 万 $\mathrm{t}$ のなたねが生産さ れ，1980 年には 100 万 $\mathrm{t}$ にまで持っていこうと計画中 である。ところがフランス人はなたね油をあまり好ま ず，国内で生産されるにかかわらず大部分を輸出に向け なければならない。1977 年には 179 千 $\mathrm{t}$ のなたね油が 国内で生産されたが消費量は 35 千 $\mathrm{t}$ で残りは全量輸出 に充当した。輸出となると手取価格は低くなり，かつ一 方で落花生油, オリブ油などを輸入しているのは不合理 と，政府も一はだぬいで，今年の春からなたね油の消費 拡大を礼らった大がかりなキャンペーンを展開すること になった。今後のなたね油の消費動向が注目されるとこ ろである。

また西独においても食用油全体の消費はあまり伸びて ないが，大豆油については消費が大幅に伸びている。 1965 年の全体の植物油消費量は $1,002.6$ 千 $\mathrm{t}$ であり, 1977 年には 1,111 千 $\mathrm{t}$ とこの 12 年間に $10.8 \%$ 増加し たにすぎない。しかしながら大豆油については 1965 年 に228.5千 $\mathrm{t}$ の消費量であったものが，1977 年には 419 千 $\mathrm{t}$ 実に $83 \%$ 方の増大を示している。綿実油，パーム 核油及び落花生油などの減少が目立つ。パーム油も近年 マレーシアの増産で消費量が増えているが，大豆油の消 費増には目をみはるものがある。そして全体の植物油の 中に占める大豆油のウエイトは 1965 年には $22.8 \%$ であ ったものが 1977 年には $37.7 \%$ に上昇した。1978 年は 西独においてもドル安のため, アメリカ大豆の入手価格 が下落し, 従って大豆油の価格も安くなり, 大豆油の消 費量は大幅に伸び，543 千 $\mathrm{t}$ と前年実績を $29.6 \%$ も上 回る警異的な数字となった。パーム油，やし油などが減
少したことと, マーガリンなどの生産も大幅に増加した こと, 更には東独を含めて東欧圈への輸出需要も増大し てきたことなどによるものである。西独の関係者は，イ ンド，パキスタン等中近東における食用油の消費量も増 加しているので, 将来的には輸送上の問題もあり東南ア ジアで生産されるパーム油ややし油などは中近東にもっ と向けられ，ECの大豆油は中近東に向けるよりも域内 で消費する方がより効率的であり，従って西独などにお ける大豆油の消費量はまだまだ増大するもの上みてい る。

つまり EC 圏においては大豆かすの需要が強く，また 大豆油の需要も, 植物油全体の需要量はほぼ横ばいにも かかわらず，着実に増加しているので，大豆搾油を目的 とした大型工場がこのところ急速に新増設されて扝り， これらは極力省力化した形での経営が行われ，その間集 約化も着実に進行しているようである。フランスでは 1950 年台には約 2,000 位の工場があったものが, 現在 ではフランス油脂協会に加盟している 312 社で $90 \%$ 以 上の原料を処理しており, 西独でも約 500 万 $\mathrm{t}$ の油脂原 料の $95 \%$ に相当するもの在 11 社で処理し, 残りの国 産原料のわずかの量が中小工場で処理する形々なってい る。そしていずれの国でも大型化，集約化は更に進行す る傾向にある。

\section{食用油業界の展望}

\section{1）製品需要は今後も増加}

製油製品である油脂と油かすの需要は今後も $3 \sim 4 \%$ 程度の伸びを続けるものとみられている。食用油の需要 予測については，社団法人日本油脂協会が昭和53年春に 日本リサーチ総合研究所に依頼して実施した。それによ ると今後数年間, 食用油の伸び率は $3.3 \%$ 程度を維持す るだろうとしている。特に家庭用と加工用，才なわらマ ーガリン，ショートニング，マヨネーズなどの分野での 伸びが大きいとしている。また農林水産省が昭和 50 年 に発表した“農産物の需要と生産の長期見通し」のなか でも, 食用油の伸び率は昭和 60 年までは年率 $3.2 \%$ 之 予測している。日本における食用油脂の摂取量は欧米先 進国に比べまだ半分程度であるから，高度成長時代のよ うに $10 \%$ とかそれに近い高率は期待できないにしても， $3 \sim 4 \%$ 程度の伸びは今後とも続くとみられている。

また油かすを代表する脱脂大豆についても，畜産製品 への需要は強く配合飼料の生産もまだ当分伸びを続ける ものとされており，他の植物性油か寸は原料の入手難か ら減少傾向にあり，一時話題にのぼった石油タンパクも 昨今の石油需給のなかでは実現は困難のようであり，飼 料用を中心に大豆かすの需要増は続くとみられている。

2) 大豆，なた称中心は今後も続く

前述のように日本の控油業界は大豆，なたねへの集中 度をたかめ，現状で全処理原料のうち $80 \%$ に達してい 
る。大豆かすとともになた祅かすも肥料用の外に飼料用 需要も高めているので, 大豆, なた㸚ともに製品の需要 は強く, 供給源としてもアメリカ, カナダともに比較的 安定的であるので, 大豆, なた齐については需要, 供給 ともにマッチした形となっており, 他の油脂原料に比べ ても優位性も高く, 大豆, なたね中心の操業は今後も続 けられるとみられている。

3) 国際化の進展

原料のほとんどを国際市場で求め, 油脂, 油かすとも に国際性の高い商品であるから，好むと好まざるとにか かわらず，今後とも国際化はますます進んでゆくと思わ れる。従って国際競争力を養い体質を強化してゆくこと が最も肝要なこととなるであろう。
4）油脂, 油かすの高度利用を

製油産業は原料価格の相場変動に加えて, 非今は変動 為替相場による激しい為替の上げ下げがあり，採算の不 安定さを一層増幅させることになった。これに対処して 各社とも省力化, コストダウン, 合理化の徹底を進め下 いる。今後更に求められるものは，いかにして油脂亡油 かすの付加価值を高めた高度利用を推進するか，それぞ れの特性を生かしたものをどうやって生み出して功くか が重要な問題となるのではなかららか。マス・プロの中 で製造された油やかすに焦点をあてた分野がよ゙う展開さ れるかが一つの問題となるであるう。

(昭和 54 年 5 月 16 日受理) 